\title{
Distribution of potentially toxic soil elements along a transect across Kazakhstan
}

Article

Accepted Version

Creative Commons: Attribution-Noncommercial-No Derivative Works 4.0

Guney, M., Yagofarova, A., Yapiyev, V., Schönbach, C., Kim, J. R. and Inglezakis, V. J. (2020) Distribution of potentially toxic soil elements along a transect across Kazakhstan. Geoderma Regional, 21. e00281. ISSN 2352-0094 doi:

https://doi.org/10.1016/j.geodrs.2020.e00281 Available at https://centaur.reading.ac.uk/90324/

It is advisable to refer to the publisher's version if you intend to cite from the work. See Guidance on citing.

Published version at: http://dx.doi.org/10.1016/j.geodrs.2020.e00281

To link to this article DOI: http://dx.doi.org/10.1016/j.geodrs.2020.e00281

Publisher: Elsevier

All outputs in CentAUR are protected by Intellectual Property Rights law, including copyright law. Copyright and IPR is retained by the creators or other copyright holders. Terms and conditions for use of this material are defined in the End User Agreement.

www.reading.ac.uk/centaur 
Central Archive at the University of Reading

Reading's research outputs online 
3 Mert Guney, ${ }^{1,5}$ Almira Yagofarova, ${ }^{2,5}$ Vadim Yapiyev, ${ }^{1,3}$ Christian Schönbach, ${ }^{4}$ Jong R. Kim, ${ }^{1}$

4 Vassilis J. Inglezakis 2,5 , $^{*}$

5

$6{ }^{1}$ Department of Civil \& Environmental Engineering, School of Engineering, Nazarbayev

7 University, Nur-Sultan, Kazakhstan

$8 \quad 2$ Department of Chemical \& Materials Engineering, Environmental Science \& Technology Group

9 (ESTg), School of Engineering, Nazarbayev University, Nur-Sultan, Kazakhstan

$10{ }^{3}$ Department of Geography and Environmental Science, The University of Reading, Reading,

11 United Kingdom

$12{ }^{4}$ Department of Biology, School of Science and Technology, Nazarbayev University, Nur-Sultan, 13 Kazakhstan

145 Environment \& Resource Efficiency Cluster (EREC), Nazarbayev University, Nur-Sultan, 15 Kazakhstan

16

17

* Corresponding author: vasileios.inglezakis@ @u.edu.kz, +7 (7172) 706534 


\section{Abstract}

23 The present study aims to investigate the distribution of selected potentially toxic elements (PTEs) 24 in Kazakhstan's topsoils. Soil samples collected across a north-south gradient $(n=40)$ near main 25 highways connecting major residential/industrial areas were characterized for their $\mathrm{As}, \mathrm{Cd}, \mathrm{Co}, \mathrm{Cr}$, $\mathrm{Cu}, \mathrm{Mn}, \mathrm{Ni}, \mathrm{Pb}$, and $\mathrm{Zn}$ content as well as for soil physio-chemical properties. The majority of the soils had neutral $\mathrm{pH}$ (no significant relationship between $\mathrm{pH}$ and PTE concentrations). The soil organic carbon was higher at the northern and farther southern parts of the transect (along with higher concentrations of PTEs in soils). As, Mn, and Ni concentrations in soils were elevated in comparison to relevant background concentrations. Critical concentrations of $\mathrm{As}, \mathrm{Cd}, \mathrm{Co}, \mathrm{Mn}$, and $\mathrm{Ni}$ (with respect to regulatory limits) were found at multiple locations, with As being particularly of potential concern (range: $8.7-42 \mathrm{mg} \times \mathrm{kg}^{-1}$ ). The distance from the nearest settlement seems to influence the soil PTE concentrations, however the relationship is not statistically significant. In total, eight locations had statistically outlier PTE concentrations for $\mathrm{Cd}, \mathrm{Mn}, \mathrm{Ni}$, and $\mathrm{Zn}$. The overall results were comparable to similar studies across the world except that the $\mathrm{Pb}$ content of the study soils was less elevated. Studies on site characterization and human health risk assessment covering identified hotspots and PTEs are recommended.

Key words: arsenic, heavy metals, Kazakhstan environment, site characterization, soil pollution 40 


\section{Introduction}

The Republic of Kazakhstan is situated in Central Asia and is the ninth largest country in the world in terms of its land area, covering more than 2.7 million $\mathrm{km}^{2}$. Kazakhstan has vast quantities of land resources (mainly minerals, oil, and gas). As a result, since gaining its independency, its government has mainly depended on the extraction of oil, gas, and minerals as well as the operation of related industries for the country's economic growth. As a result, Kazakhstan is the political leader among Central Asian countries with an economy showing the strongest performance with a continuous growth momentum (Makhmutova, 2018).

The current economic growth in Kazakhstan is mainly fueled by the exploitation of its land resources and accompanying booming sectors of construction and government services, and this may have negative effects on the environment such as problems related to contamination including of water and soil (Kuroda et al. 2005). Kazakhstan's soils not only show a tendency of being affected from land degradation, desertification, and salinization due to natural and anthropogenic factors but also may be under environmental strain due to contamination by heavy metals. This could negatively affect public health as well as economy via a reduction in land productivity, stability, functions, and services depending on the exploitation of its natural systems.

A limited number of localized studies have investigated environmental problems in different regions of the country, some also focusing on the potentially toxic elements (PTEs) in soils: Mueller et al. (2014) investigated the level of heavy metals in oil-polluted soils in Atyrau region, the reported concentrations of measured $\mathrm{Pb}, \mathrm{Co}, \mathrm{Ni}, \mathrm{Cd}, \mathrm{Cu}, \mathrm{Zn}, \mathrm{V}$, and $\mathrm{Mo}$ were 2-12 times higher than the maximum permissible concentrations (MPCs) stated in legislation. The researchers state that the oil-polluted soil became an accumulator and a storage for hazardous forms of the heavy metals which could migrate to the Caspian Sea and thus could cause problems of larger 
scale. Also, they investigated hazardous mobile forms of $\mathrm{Cu}, \mathrm{Pb}, \mathrm{Ni}, \mathrm{Zn}$, and $\mathrm{Cd}$ in large rice irrigation farms in southern Kazakhstan, which showed that heavy metal concentrations impacted soil fertility in agricultural areas where mobile forms of measured heavy metals accumulated in soil profile, making hazardous metals potentially available to crop plants and in drinking water. Ramazanova (2016) investigated $\mathrm{Pb}, \mathrm{Zn}, \mathrm{Cd}, \mathrm{Cu}$, and $\mathrm{Fe}$ in soils near central heating power plants at the different distances (50-5000 m) in Almaty: The levels of Fe and $\mathrm{Zn}$ in soils complied with the MPCs; however, the $\mathrm{Cd}$ and $\mathrm{Pb}$ concentrations were five to ten times higher than the MPCs. Bayandinova et al. (2018) investigated heavy metals, hydrocarbons, nitrogen and carbon oxides, and organic compounds in air, water resources, and soil at East Kazakhstan region. Specifically, $\mathrm{Cd}, \mathrm{Cu}, \mathrm{Pb}$, and $\mathrm{Zn}$ were investigated in soils near smelters at distances from $<1 \mathrm{~km}$ to $3 \mathrm{~km}$ near Ust-Kamenogorsk, Semey, and Ridder. Elemental concentrations were higher than the MPCs in all investigated districts of Ust-Kamenogorsk in spring and autumn campaigns, the same was also observed in Ridder and Semey. Specifically, the concentrations of $\mathrm{Pb}, \mathrm{Cd}$, and $\mathrm{Zn}$ were noted as very high one $\mathrm{km}$ near the large power plants. Muzychenko et al. (2017) studied the $\mathrm{Pb}$ pollution in the roads of Almaty and found high concentrations attributed to traffic as well as the industrial and geological history of the region. Finally, Mukasheva et al. (2013a, 2013b) monitored Cr, Cu, $\mathrm{Cd}, \mathrm{Pb}, \mathrm{Zn}, \mathrm{Ni}, \mathrm{V}$, and $\mathrm{Mn}$ pollution near Temirtau, Balkhash, and Karaganda towns. All these cities are industrial centers with large smelters and plants near or inside the city boundaries such as Karaganda Steel Mill and chemical plants "Jambul Cement" and "ArcelorMittal" in Temirtau. Their comparative data analysis showed that the concentration of heavy metals in all soil samples exceed the MPCs and heavy metals could accumulate in soil and crop plants.

Although a number of localized studies already indicate environmental adverse impact from anthropogenic activities, a systematic study that is reporting soil quality conducted on a larger 
87 scale is missing in the literature. Although Kazakhstan is the economical leader of Central Asia

88 and one of the major developing countries around the world, the environmental consequences of

89 this expansion has not yet been well studied. As a part of a large study that aims to investigate

90 Kazakhstan's soils in terms of its physical and chemical properties (Yapiyev et al. 2018),

91 contamination status, and nutrient potential, the present study aims to investigate the distribution of

92 selected PTEs (As, Cd, Co, Cr, Cu, Mn, Ni, Pb, and $\mathrm{Zn}$ ) in topsoils of Kazakhstan collected

93 through a north-south transect $(\mathrm{n}=40$, sampling sites approx. $50 \mathrm{~km}$ apart) near highways

94 connecting numerous major residential/industrial landmarks of the country. We aim to identify

95 hotspots as well as relationships between individual PTE concentrations and site/soil properties.

96 Establishing a baseline about the current status is important as this not only help identify potential

97 problem areas but also could be used to compare with the future monitoring and later to predict the 98 dynamics of the change.

\section{Materials \& Methods}

101

102

\subsection{Sampling Area, Sampling and Sample Handling}

103

Soil samples $(n=40)$ have been collected in September 2016 (Fig. 1) from sampling sites

104 located a minimum of $50 \mathrm{~m}$ away from the nearest road. The sample from the northernmost point 105 was collected near Petropavlovsk city (5454'N, 6906'E) and the southernmost sample was collected near Chu river (4255'28', N, 7311'6' 'E). During sampling, following the removal of the litter layer if present (approximately the top $2 \mathrm{~cm}$ ), drilled samples were cored from approximately 0-15 cm. The samples, then, were air-dried in the laboratory, sieved to $<2 \mathrm{~mm}$, and stored at room temperature until analyzed (see also Methods section in Yapiyev et al. (2018)). 


\subsection{Laboratory Analyses}

112 Soil $\mathrm{pH}$ was measured in soil suspension using 8107UWMD Ross Ultra pH/ATC triode

113 electrode (Thermo Fisher Scientific, USA) and an Orion 013010MD conductivity cell electrode

114 (Thermo Fisher Scientific, USA). Soil organic carbon (SOC) was measured using a C/N dry 115 combustion elemental analyzer (Multi N/C 3100, Analytic Jena). Samples were pre-treated on the 116 combustion boat by adding $100 \mu \mathrm{L}$ of $\mathrm{H}_{3} \mathrm{PO}_{4}(30-40 \%$ w/w) to $100 \mathrm{mg}$ milled soil to dissolve 117 carbonates first. The samples were then dried overnight at $70{ }^{\circ} \mathrm{C}$ and finally subjected to 118 combustion at $950{ }^{\circ} \mathrm{C}$ under $14 \mathrm{~L} \times \min ^{-1}$ oxygen flow (see also Methods section in Yapiyev et al. 119 (2018))

120 The selected PTEs were measured using ICP-MS iCAP RQ. Sample digestion was first 121 conducted via a microwave system (Multiwave PRO by Anton Paar). Soil samples were dried for $12248 \mathrm{~h}$, crushed, and sifted through $150 \mu \mathrm{m}$ sieve. Then, $1 \mathrm{~g}$ of soil was weighed accurately at $0.1 \mathrm{mg}$ 123 (Radwag XA52/Y) and then was transferred into a vessel. $9 \mathrm{~mL} \mathrm{HCl}(37 \% \mathrm{w} / \mathrm{w})$ and $3 \mathrm{~mL}$ of $124 \mathrm{HNO}_{3}(68-70 \% \mathrm{w} / \mathrm{w})$ were added separately to the vessel, and samples were digested at $140{ }^{\circ} \mathrm{C}$ for $12540 \mathrm{~min}$. After the digestion has been complete, all vessels were cooled, then the digestates were 126 filtered through Whatman No. 1 or equivalent filter paper (11 $\mu \mathrm{m}$ pore size). After cooling and 127 filtering, solutions were collected in a volumetric flask and then diluted to $50 \mathrm{~mL}$. The reagent 128 blanks were carried out in parallel with each experimental analysis, All analyses were conducted in 129 duplicates. Furthermore, for quality control purposes the reference material BGS 102 was digested 130 and the concentrations of PTEs were measured using ICP-MS iCAP RQ. The concentrations of 131 measured $\mathrm{Cr}, \mathrm{Cu}, \mathrm{Ni} \mathrm{Pb}, \mathrm{Zn}$ were close to certified values (i.e. within $20 \%$ ), except for $\mathrm{Cd}$ where 
132 the difference between measured and certificated $\left(0.275 \pm 0.182 \mathrm{mg} \times \mathrm{kg}^{-1}\right)$ concentration was 133 about $40 \%$.

\subsection{Data Processing and Statistical Analyses}

136 Apart from calculations performed for determining selected descriptive statistics (average, 137 minimum, maximum, standard deviation, coefficient of variation, skewness, kurtosis), The Pearson

138 correlation tests have been conducted to check the relationship between (a) individual PTE 139 concentrations, (b) PTE concentrations and soil physio-chemical properties, and (c) PTE 140 concentrations and distance of sampling sites from nearest settlement (a settlement defined as a 141 residential zone with population $>1,000$ ). Sampling points were also categorized into two groups 142 according to their distance from the nearest settlement; the first including points relatively close to 143 the nearest settlement (distance $<10 \mathrm{~km}, \mathrm{n}=20$ ) and the second consisting of points relatively far 144 from the nearest settlement (distance $>10 \mathrm{~km}, \mathrm{n}=20$ ) where exact distances are presented in the 145 Supplementary material (Supplementary Table 1). These groups were compared via two sample $t$ 146 test in order to see whether there are differences between PTE concentrations. Shapiro-Wilk test 147 along with Q-Q plots have been employed to check the distribution of data with the specific 148 purpose of identifying outlier PTE concentrations. Furthermore, a box plot visually representing 149 the data for potentially toxic elements has been prepared (Fig. 3) via software (IBM SPSS 25). 150 Outliers have also been determined. which consist of points with concentrations of PTEs larger 151 than $1.5 \times \mathrm{IQR}$ (interquartile range, the difference between the third and the first quartiles). 


\subsection{Soil Properties}

156 The $\mathrm{pH}$ of the samples (Supplementary Table 1) ranged from 5.32 to 9.18. The majority of the

157 samples had neutral $\mathrm{pH}$ (between 6 and 8) except two samples that can be categorized as acidic

158 (with $\mathrm{pH}<6$, sampling locations: S7, S10) and 11 samples that could be classified as alkaline 159 (with $\mathrm{pH}>8$ : S25-S32, S35, S37-S38). The $\mathrm{pH}$ has a significant effect on the mobility of trace

160 metals in soil such that at a lower $\mathrm{pH}$ the sorption capacity of soil is lower than that at neutral or 161 alkaline $\mathrm{pH}$, Consequently, the mobility of most part of metals decreases from acids soils to 162 alkaline. Soil samples from the present research are mostly neutral therefore the expected mobility 163 of metal forms is generally at the lower end. There was also a trend that through the north-south 164 transect (Fig. 2, based on data from Yapiyev et al. (2018)), the soils samples become more alkaline 165 from north to south which could be linked to more arid climate conditions and dominance of 166 calcareous soils (Slessarev et al. 2016) .

167 The amount of SOC in soil (Supplementary Table 1) influences, among many other things, the 168 mobility and bioavailability of various elements by binding them into its complex structure and 169 thus limiting their mobility at higher SOC values. The SOC content of study soils ranged of $0.38 \%$ 170 to $4.09 \%$ showing that the study samples collected through the transect were mainly mineral 171 (inorganic) soils. Through the north-south transect, higher SOC values (> 2\%) identifying 172 potentially organic soils have been observed specifically in the north (S3, S5-S9, S12, S14, S16) 173 and farther south (S34, S36-S40). These zones are also inside the country's two important arable 174 regions, therefore, such an observed specific elevated profile of SOC would be expected.

175

176

\subsection{Concentrations of PTEs in Soils}


The levels of potentially toxic elements (PTEs) were first compared with the background

178 concentrations of Canadian and Chinese soils (Tables 1 and 2). The background levels may be

179 useful in order to estimate the differences between natural content of metals including their

180 geochemical composition as source and the fraction coming from contamination sources (Santos-

181 Frances et al. 2017). The background concentrations of Canadian (MDDELCC 2019) and Chinese

182 (Huamain et al. 1999) soils were used since in certain parts of these countries, the climate as well

183 as the conditions that the surface soils had been developed were comparable to those in

184 Kazakhstan.

185 The comparison with the Canadian soil background levels showed that particularly As

186 concentrations were above background levels such that all of the samples from the present study

187 had As concentrations larger than $6 \mathrm{mg} \cdot \mathrm{kg}^{-1}$, corresponding to an average As concentration in the

188 study soils was 20.8 mg. $\mathrm{kg}^{-1}$. Considering the other PTEs, Mn and Ni average concentrations were

189 also higher than corresponding background values (34 of 40 points for Mn and 29 of 40 points for

$190 \mathrm{Ni}$ exceeded the background value). The levels of $\mathrm{Co}, \mathrm{Cr}, \mathrm{Cu}$, and $\mathrm{Zn}$ were comparable to the

191 Canadian background levels (i.e. with comparable average vales) whereas $\mathrm{Pb}$ concentrations were

192 lower (only five points exceeding the background level) and Cd concentrations were much lower

193 (all points below the background level) than the Canadian background concentrations.

194 The comparison of PTE concentrations from the present study with Chinese soil background 195 values (which reported values are lower than the Canadian background values except for As)

196 showed that the found concentrations were higher for $\mathrm{As}, \mathrm{Cd}, \mathrm{Cr}, \mathrm{Cu}, \mathrm{Ni}$, and $\mathrm{Zn}$; and were

197 comparable for $\mathrm{Pb}$. No element had systematically lower concentrations than the background

198 values (no background values were present for Co or Mn therefore no comparison could be made). 
Overall, the comparison of the PTE concentrations in the study soils with the background concentrations of soils of China and Canada indicated high concentrations of especially As and of $\mathrm{Mn}$ and $\mathrm{Ni}$. The evidence regarding the elevated $\mathrm{Cd}, \mathrm{Cr}, \mathrm{Cu}$, and $\mathrm{Zn}$ concentrations was less clearly cut.

The results from the soils of the present study were also compared with regulatory standards

of Kazakhstan and Russia (which share the same regulatory limits), China, and Canada for soils.

Regarding the regulatory standards of Kazakhstan (MEPRK 2004) and Russia (RPR 2006), for As,

$\mathrm{Co}, \mathrm{Cr}, \mathrm{Ni}$, and $\mathrm{Zn}$, the measured concentrations exceeded the maximum permissible concentrations (MPCs) in every single sample. The majority of the samples also exceeded the criteria for $\mathrm{Cu}$ (35 of 40 samples) and $\mathrm{Pb}$ (22 of 40 samples) whereas for $\mathrm{Mn}$ and $\mathrm{Cd}$, less samples had concentrations higher than the MPC (19 and 9, respectively, of 40 samples). That being said, many MPCs presented in Kazakh and Russian regulations seem low or very low even in comparison to natural background concentrations of these elements as in the cases of: As (MPC: references that provide a scientific rational for these regulations it is not possible to evaluate the scientific soundness of these limits. Consequently, it may be recommended to not to depend on these comparisons alone for evaluating the levels of PTEs of the study soils.

When the results from the present study have been compared to the regulatory standards in

Canada for residential soils (MDDELCC 2019), the only element with systematically high concentrations in topsoils was Mn (concentrations exceeding the limit at 34 of 40 points). Also, As, Co, and $\mathrm{Ni}$ concentrations were high in five, four, and six points, respectively. This 
222 possible contamination with three or more elements: S8 (with As, Co, Mn, and Ni), S35 (with Co, $223 \mathrm{Mn}$, and Ni), S36 (with As, Co, Mn, and Ni), and S39 (with As, Mn, and Ni).

A similar comparison with the Chinese environmental quality standards (MEPPRC 1995)

225 226

showed that $\mathrm{Cd}$ and $\mathrm{Ni}$ concentrations were higher than the stated norms at the majority of the points (24 and 29 points, respectively, out of 40 ). This is mainly because the Chinese regulation has stricter limits for $\mathrm{Ni}$ and $\mathrm{Cd}$ in comparison to the Canadian regulation. Parallel to the above comparison, the As concentrations were higher than the norm at five locations. This comparison identified seven sampling locations with elevated PTE concentrations indicating possible contamination with three or more elements: $\mathrm{S} 7$ (with $\mathrm{Cd}, \mathrm{Cr}$, and $\mathrm{Ni}$ ), S8 (with $\mathrm{As}, \mathrm{Cd}$, and $\mathrm{Ni}$ ), S9 (with As, Cd, and Ni), S19 (with As, Cd, Ni, and Zn), S28 (with Cd, Cu, and Ni), S36 (with As, $\mathrm{Cd}$, and $\mathrm{Ni}$ ), and $\mathrm{S} 39$ (with $\mathrm{As}, \mathrm{Cd}$, and $\mathrm{Ni}$ ). The common locations with the comparison to Canadian standards were S8, S36, and S39.

\subsection{Analysis of Concentrations and Potential Hotspots}

The descriptive statistics for PTEs in the study soils (Table 2) provided no average values or ranges at the extreme ends for the selected PTEs. As discussed previously, a comparison of the elemental averages to Canadian and Chinese environmental norms indicated As and $\mathrm{Ni}$ (by both regulations) as well as $\mathrm{Cd}, \mathrm{Co}$, and $\mathrm{Ni}$ (according to one of the regulations) as PTEs exceeding norms at some locations. The coefficient of variation values fell in a normal range except that it was higher for $\mathrm{Pb}$, possibly due one outlier point with high concentration (S11). The skewness of the data was to the left for all PTEs, indicating a pooling of values at the lower range while a few points with higher concentrations extended the distribution tail to the right end, which could be reasonably expected for the soil PTE concentration data from this site. Finally, the data were 
245 leptokurtic for the majority of the elements as expected, with the exception of $\mathrm{Cr}$ and $\mathrm{Cu}$ having 246 flatter distribution than the other elements which may indicate anthropogenic disturbances.

247 Inter-element relationships may provide information on the sources and pathways of PTEs.

248 According to the Pearson correlation coefficients (Table 3), the concentrations in eight of the nine 249 selected PTEs (with the exception of $\mathrm{Pb}$ ) are significantly correlated with each other at $p<0.01$ 250 level. It is known that the behavior of metals in soils are controlled by a number of key parameters 251 (USEPA 1992) including the soil's $\mathrm{pH}$ and cation exchange capacity (which is mainly defined by 252 soil organic matter and clay content of the soil) when cations are of concern. As a result, it may be 253 expected to observe such a correlation between elemental concentrations in a set of soil samples as 254 certain soil physio-chemical properties control the mobility and retention of a variety of PTEs in a 255 similar fashion. The fact that $\mathrm{Pb}$ has a set of correlations with other PTEs with lower and/or with 256 less/not significant values may be due to different reasons. In terms of its affinity to soils and soil 257 constituents, $\mathrm{Pb}$ has a high relative order of sorption (USEPA 1996) and consequently it is one of 258 the least mobile heavy metals in soils. As a result, other PTEs in soil might have exhibited 259 relatively higher mobilization rates in the past which leading to a reduction in their soil 260 concentrations with time. Another possibility is that $\mathrm{Pb}$ might be introduced to the environment 261 from overland traffic activities (the samples locations have been accessible sites from nearby 262 highways) therefore shows a different concentration profile than the other PTEs. This, however, is 263 unlikely as $\mathrm{Pb}$ tends to accumulate mostly within the nearby soils, particularly within the first $10 \mathrm{~m}$ 264 whereas the sampling locations were located a minimum of $50 \mathrm{~m}$ away from the nearest road. That 265 being said, the overland traffic activities introduce to the environment not only $\mathrm{Pb}$ but also $\mathrm{Cu}$ and 266 Zn (Guney et al. 2010), and in the present study Pb is also correlated with these PTEs at 0.01 level, 267 therefore, this may require further investigation in the future. 
The correlation between PTEs concentrations and soil $\mathrm{pH} \&$ SOC (Table 4) showed that 269 although the concentrations of the majority of PTEs showed an inverse correlation with $\mathrm{pH}$, the 270 values were not statistically significant. Therefore, the $\mathrm{pH}$ of the soils was not a major parameter 271 controlling the PTE concentrations in soil. On the contrary, the SOC values were positively and 272 significantly correlated with PTE concentrations. The soil organic matter significantly contributes 273 to cationic and anionic exchange capacities, therefore may be expected to increase the retention of 274 PTEs in soils.

275 For the two categories of points according to their distance from the nearest settlement 276 (population $>1,000)$, the points that are relatively closer to the nearest settlement $(<10 \mathrm{~km}, \mathrm{n}=$ 277 20) had their average concentrations of the majority of the PTEs (Table 5) higher than that of the 278 points that are relatively farther $(>10.0 \mathrm{~km}, \mathrm{n}=20)$. However, the two sample $t$-test indicated that 279 the difference between the concentrations of PTEs was only significant for Cr. Although it first 280 seems that the settlements have an impact on the topsoil concentrations of PTEs, this impact is not 281 statistically significant. An analysis of Pearson correlations between the concentrations of 282 individual PTEs and the distance of the sampling location from the nearest settlement (Table 6) 283 also indicated negative correlations for the majority of the elements: however, the values were low 284 and were significant at 0.05 level only for three elements. Therefore, it is not possible to talk about 285 a significant impact of settlements on the PTE concentrations of topsoils. Such a significant impact 286 may not have been observed due to the fact that some of the settlements are not large enough to 287 have a major impact on nearby soils via anthropogenic activities. It is also possible that the impact 288 of anthropogenic activities may not be significant due to relatively large distances between 289 settlements and sampling locations. 
291 histograms with the specific purpose of identifying outliers having excess concentrations of PTEs.

292 The data showed normal distribution only for As, Cr, Mn, and $\mathrm{Zn}$. An examination of test results

293 together with Q-Q plots and histograms revealed eight locations with outliers: one location with 294 three outliers (S36 for Cd, Mn, and Ni), two locations with two outliers (S10 for Cd and Mn, S32 295 for $\mathrm{Cd}$ and Zn), and five locations with one outlier concentration (S7, S9, S11, S19, and S28). A 296 more detailed discussion is presented below regarding the identification of specific sampling 297 locations of concern in terms of elevated PTE concentrations. Finally, the box plot analysis 298 identified similar locations with outlier concentrations: at S10 (Pb), S11 (Pb), S32 (Cd), S35 (Co), 299 and S36 (Co, Mn, Ni).

300 Based on the previously presented comparison with the background concentrations and the 301 regulatory limits from selected countries, the PTEs of concern for the present study could be 302 identified as $\mathrm{As}$, and to a lower extent $\mathrm{Cd}, \mathrm{Mn}$, and Ni. In terms of locations, a comparison to 303 regulatory limits and the statistical analyses yielded varying results (Canada: S8, S35, S36, S39; 304 China: S7, S8, S9, S19, S28, S36, S39; statistical analyses: S36, S10, S32, S7, S9, S11, S19, S28). 305 At the end, it is possible to identify five locations as potential hotspots: The location S36 has been 306 unanimously identified as a potential hotspot. Similarly, S8 and S39 are two other potential 307 hotspots identified by the comparison to regulatory limits. Finally, it is worth to consider S10 and 308 S32 as potential hotspots as they are pointed by the statistical analyses having outlier 309 concentrations at each location. It is interesting to note that none of these three points are near 310 large settlements or under the direct nearby influence of industrial activities. The elevated 311 concentrations of some PTEs at these locations might be due to natural sources or might result 312 from long-distance impact of anthropogenic activities such as smelting. It should be noted that the 
sampling locations have been selected on a random basis to represent the topsoil concentrations of

314 selected PTEs and a direct investigation of contamination sources for PTEs was not the major goal.

315 Therefore, at these five locations (S36, S8, S39, S10, and S32), further investigation and site

316 characterization involving multiple sampling locations and taking potential human exposure into

317 account is recommended.

318 Among five points identified above as potential hot spots for their elevated PTE 319 concentrations by a comparison to regulatory limits and/or via statistical means, their soil types 320 included chernozem (S8, S10), arenosol (S32), regosol (S36), and umbrisol (S39). Chernozems are 321 soils rich in organic matter commonly found in the steppes of Eurasia up to Siberia. The SOC for 322 S8 and S10 were $2.41 \%$ and $1.63 \%$, respectively. The elevated concentrations of PTEs in S8 (As, $323 \mathrm{Co}, \mathrm{Cd}, \mathrm{Mn}$, and $\mathrm{Ni}$; according to regulations) and $\mathrm{S} 10(\mathrm{Cd}, \mathrm{Mn}, \mathrm{Pb}$; identified as outliers via 324 statistical analyses) may be attributed to cation retention mechanisms from organic matter limiting the mobility of elements. Umbrisols are also steppe environment soils, characterized by a surface layer that is rich in humus. Similar to S8 and S10, this may explain high concentrations of PTEs in S39 (As, Cd, Mn, and Ni; according to regulations). Regosols are weakly developed soils, a characteristic of eroding landscape, and it not easy to comment on their properties due to unconsolidated material they are formed and a lack of soil horizons. However, regarding the presence of PTEs, S36 is close to other sampling locations with umbrisol soil type (S37 to S39), therefore, high concentrations of PTEs in S36 (As, $\mathrm{Co}, \mathrm{Cd}, \mathrm{Mn}$, and $\mathrm{Ni}$; according to regulations) would be partly explained by the similarities to the concentrations in neighboring sampling points (e.g. S39). Arenosols, on the contrary, may be expected to have generally low PTEs due to their sandy nature accompanied by low humus and clay content. Therefore, outlier $\mathrm{Cd}$ and $\mathrm{Zn}$ concentrations at S32 warrant further investigation where possible explanations include 
contaminated dust fallout from industrial facilities or of geogenic origin e.g. relatively common sulfide minerals greenockite $(\mathrm{CdS})$ and wurtzite $(\mathrm{ZnS})$.

\subsection{Comparison to Studies Investigating Similar Sites}

soils tends to mainly repeat those in the Earth's crust (Alekseenko et al. 2014). It also indicated

that certain elements tend to be more abundant in urban soils than the Earth's soils in general, including some of the PTEs ( $\mathrm{As}, \mathrm{Cd}, \mathrm{Co}, \mathrm{Cu}, \mathrm{Pb}$, and $\mathrm{Zn}$ ) subjected in the present work.

A comparison of the results from the present study to studies in China (where rural areas with similar climate to the present study sampling locations and under influence of nearby anthropogenic activities are common) indicated similar findings. Cheng (2003) reviewed the contamination by heavy metals (focus on $\mathrm{Cd}, \mathrm{Cu}, \mathrm{Pb}$, and $\mathrm{Zn}$ ) in different areas of China including rural and agricultural areas. The background levels of heavy metals in soils were low, but human activities have been shown to pollute soil, water, and air where metals may be transferred to plants and food; three identified main sources of contamination being industrial emissions, wastewater, and solid waste. The reported heavy metal concentrations were within the range in the present study, with the exception of $\mathrm{Cd}$ being higher and $\mathrm{Zn}$ and $\mathrm{Cr}$ being also slightly more elevated. Another review of heavy metal contaminations in urban soils, road dusts, and agricultural soils from China (Wei et al. 2010) showed that among selected elements (Cr, Ni, Cu, Pb, Zn, As, $\mathrm{Hg}$, and $\mathrm{Cd}$ ), the geoaccumulation index of urban soils showed $\mathrm{Cu}, \mathrm{Pb}, \mathrm{Zn}$ and $\mathrm{Cd}$ enrichment and of agricultural soils had elevated concentrations of $\mathrm{Cd}, \mathrm{Hg}$, and $\mathrm{Pb}$ due to anthropogenic activities with various sources (mining, sewage sludge, pesticides, fertilizers, traffic emission, electroplating 
plant, spring factory, band steel factory, leather factory, petrochemical complex, etc.) noted as the

360 main sources of trace metals contamination. The contents of PTEs were in general comparable to

361 the present research. Liao et al. (2007) has performed a geochemical survey of soils of Jiangsu

362 Province, China for 54 elements in 103,000 top-soil samples and presented similar results

363 regarding PTE concentrations. They reported that for eight PTEs (As, $\mathrm{Cd}, \mathrm{Hg}, \mathrm{Pb}, \mathrm{Ni}, \mathrm{Cr}, \mathrm{Cu}$, and

$364 \mathrm{Zn}$ ), the measured concentrations of these PTEs were higher than their natural background at $40 \%$

365 of the samples (with over 10\% of the land being classified as contaminated). Finally, Zhao et al.

366 (2010) considered anthropogenic activities as the reason of PTE contamination of Yangtze River

367 Delta region. They analyzed selected PTEs $(\mathrm{Cu}, \mathrm{Zn}, \mathrm{Pb}, \mathrm{Cr}, \mathrm{Ni}, \mathrm{Cd}$, and $\mathrm{Hg})$; among these, the

368 concentrations of $\mathrm{Cu}, \mathrm{Zn}$, and $\mathrm{Pb}$ significantly exceeded background levels.

369 Other studies of comparable nature to the present study have reported similar results to the 370 present study with a few caveats. The levels of some PTEs (As, $\mathrm{Cd}, \mathrm{Co}, \mathrm{Cu}, \mathrm{Fe}, \mathrm{Ni}, \mathrm{Pb}, \mathrm{Mn}, \mathrm{Mg}$, 371 and $\mathrm{Zn}$ ) in soil near smelters in the Sudbury region in Ontario, Canada (a region with comparable 372 climate and soils to the present study) were monitored (Nkongolo et al. 2008). The 373 concentrations of PTEs were within the limits set by Ontario Ministry of Environment and 374 Energy (OMEE) guidelines (which are similar to MDDELCC guidelines from Quebec, Canada 375 used in the present study), even in sites within the vicinity of the Falconbridge Smelters. A 376 comparison to the concentrations in the present study showed similar PTE levels except for 377 higher $\mathrm{Co}, \mathrm{Mn}, \mathrm{Ni}$, and $\mathrm{Zn}$ content in the present research, where presumably a strict 378 enforcement of guidelines in Ontario may have led to such a difference. The concentrations of 379 PTEs reported by Nezat et al. (2017) in urban soils of Spokane, Washington also reported similar 380 results to the present study with the exception that they reported elevated $\mathrm{Pb}$ concentrations which 381 has been likely due to lead-based paint or vehicle emissions in urban zones. A study conducted on 
382 urban soils of Yerevan city, Armenia (Tepanosyan et al. 2017) reported similar concentrations of

383 PTEs and some enrichment in urban zones with the exception of clearly elevated $\mathrm{Pb}$ concentrations

384 attributed to the historical pollution in the study zone. These findings on $\mathrm{Pb}$ are also parallel to the

385 findings of Turner et al. (2018) in urban soils of Plymouth, UK who reported elevated $\mathrm{Pb}$ due to

386 contamination by paint. Also, $\mathrm{Pb}$ contamination tends to decrease to the background value at about

$38770 \mathrm{~m}$ or more roadside distance (Yan et al. 2013). This is in agreement with our findings as the

388 soils of the present study did not exhibit an extensive contamination by $\mathrm{Pb}$ because all samples

389 were taken from locations with relatively limited impact of transportation (sampling locations at

390 least 50 m away from the roads) or urban activities (many sampling locations distant from urban

391 settlements). Still, such an impact might be important for other PTEs as different studies indicate

392 that both local and distant sources of anthropogenic emissions may still lead to enrichment of PTEs

393 in non-urban soils e.g. in national park soils in Poland by $\mathrm{Pb}, \mathrm{Zn}, \mathrm{Cu}$ and $\mathrm{Mn}$ (Mazurek et al. 2017)

394 and in soils from forests and protected areas in Romania by $\mathrm{Pb}, \mathrm{Zn}, \mathrm{Cu}, \mathrm{Cr}$, and $\mathrm{Cd}$ (Ungureanu et

395 al. 2017). Finally, a very large soil survey covering the entire Europe and analyzing more than

39615,000 surface soil samples have proposed $28.3 \%$ of the total surface area of the EU for further

397 assessment because one or more of the elements (among As, $\mathrm{Cd}, \mathrm{Cr}, \mathrm{Cu}, \mathrm{Hg}, \mathrm{Pb}, \mathrm{Zn}, \mathrm{Sb}, \mathrm{Co}$ and

$398 \mathrm{Ni}$ ) exceed the applied threshold concentration, identifying both natural background and

399 historical/recent industrial and mining areas as potential sources. Similarly, the present study

400 identified eight locations with at least outlier elemental concentration as pointed out by the 401 statistical analyses (corresponding to $20 \%$ of 40 sampling locations).

402

403

\section{Conclusions}


As a rapidly developing country, Kazakhstan relies on its vast land resources of minerals, oil, and gas together with related industries, which may create a major burden on its environment. Soil 406 is an important and now scarce resource and its contamination by potentially toxic elements 407 (PTEs) may limit its usability for agricultural and urban purposes. The present study investigated 408 the distribution of selected PTEs (As, $\mathrm{Cd}, \mathrm{Co}, \mathrm{Cr}, \mathrm{Cu}, \mathrm{Mn}, \mathrm{Ni}, \mathrm{Pb}$, and $\mathrm{Zn}$ ) in topsoils of 409 Kazakhstan collected through a north-south transect at 40 locations. The analyses have shown that 410 the soils from the study area were mostly neutral in terms of $\mathrm{pH}$, with a tendency of having more 411 alkaline samples as moved from north to south. The statistical analyses didn't indicate a significant 412 relationship between $\mathrm{pH}$ and the PTE concentrations. The soil organic carbon was higher at the 413 northern and farther southern parts of the sampling transect and these locations also had higher 414 concentrations of PTEs in soils. A comparison of PTEs to background concentrations of soils in 415 two countries with similar climate and soil properties (China and Canada) indicated elevated 416 concentrations of As, $\mathrm{Mn}$, and Ni in soils. A comparison to regulatory limits of China, and Canada 417 also indicated critical concentrations of $\mathrm{As}, \mathrm{Cd}, \mathrm{Co}, \mathrm{Mn}$, and $\mathrm{Ni}$ in multiple locations (Some of the 418 regulatory limits of Kazakhstan and of Russia were very low and the scientific basis for 419 establishing these limits was not disclosed; thus, conclusions based on these limits are not 420 emphasized here). Although the distance of the sampling locations from the nearest settlement 421 (population > 1,000) seemed to influence the PTE concentrations, the relationship was not 422 statistically significant. Further statistical analyses identified eight locations with outlier PTE concentrations: S36 for $\mathrm{Cd}, \mathrm{Mn}$, and Ni, S10 for $\mathrm{Cd}$ and $\mathrm{Mn}, \mathrm{S} 32$ for $\mathrm{Cd}$ and $\mathrm{Zn}$ ), and five 424 locations for one element (S7, S9, S11, S19, and S28). Overall, the results of the present study 425 426 were comparable to previously conducted studies around the world at locations with similar properties with the specific remark that the $\mathrm{Pb}$ content of soils was less elevated than some other 
427 study locations with a history of anthropogenic impact. Studies aiming the site characterization and 428 human health risk assessment on identified hotspots (particularly at S36 as identified via 429 comparison to legislations and by statistical investigations) and PTEs (particularly for As that is 430 elevated at most locations) are recommended.

\section{Acknowledgements}

The present research was supported in part by the grant "Kazakhstan soil microbiome: agricultural characteristics and perspectives" in the framework of the agreement \#104 dated 12.02.2015 of the program \#055 "Scientific and/or Scientific-Technical Activities" within subprogram \#101 "Research Grant Funding" from the Ministry of Education and Science of the Republic of Kazakhstan and by Nazarbayev University. The authors also acknowledge financial support from Nazarbayev University Small Grant Program with code SOE2018020.

\section{Conflict of Interest:}

441 The authors declare that they have no conflict of interest. 


\section{References}

444 Alekseenko, V., Alekseenko, A. (2014). The abundance of chemical elements in urban soils. Journal of Geochemical Exploration, 147, 245-249.

Bayandinova, S., Mamutov, Z., Issanova, G. (2018). Man-Made Ecology of East Kazakhstan, Springer, Singapore.

Cheng, S. (2003). Heavy metal pollution in China: origin, pattern and control. Environmental Science and Pollution Research, 10, 192 - 198.

Guney, M., Onay, T.T., Copty, N.K. (2010). Impact of overland traffic on heavy metal levels in highway dust and soils of Istanbul, Turkey. Environmental Monitoring and Assessment, $164,101-110$.

Huamain, C., Chunrong, Z., Cong, T., Yongguan, Z. (1999). Heavy Metal Pollution in Soils in China: Status and Countermeasures. Ambio, 2, 130-134.

Kuroda, H., Eckermann, R., Gauvreau, E., Haryanto, A., Lee Ch.-H. et al. (2005). The Annual Report of Asian Development Bank. Asian Development Bank, Singapore.

Liao, Q-L., Evans, L., Gu, X., Fan, D-F., Jin, Y., Wang, H. (2007). A regional geochemical survey of soils in Jiangsu Province, China: Preliminary assessment of soil fertility and soil contamination. Geoderma, 142, 18-28.

Makhmutova, E.V. (2018). Central Asia in Search for Its Own Way of Integration. Mgimo Review of International Relations, 4, 78-91.

Mazurek, R., Kowalska, J., Gasiorek, M., Zadrozny, P., Jozefowska, A. et al. (2017). Assessment of heavy metals contamination in surface layers of Roztocze National Park forest soils (SE Poland) by indices of pollution. Chemosphere, 168, 839-850. 
MDDELCC (Ministère du Developpement durable, Environnement et Lutte contre les Changements Climatiques du Québec) (2019). Annex 2: Tableau 1: Politique de protection des sols et de réhabilitation des terrains contaminés. Accessed on: 27 April 2019. http://www.environnement.gouv.qc.ca/sol/terrains/guide-intervention/annexe2.pdf.

Mueller, L., Saparov, A., Lischeid, G. (2014). Novel Measurement and Assessment Tools for Monitoring and Management of Land and Water Resources in Agricultural Landscapes of Central Asia. Springer, Switzerland.

Mukasheva, M.A., Mukasheva, G.Z., Nugumanova, S.M., Kazimova, A.E. (2013a). Pollution of the soil cover of the industrial city with heavy metals. Journal of Chelyabinsk University, $298,152-154$.

Mukasheva, M.A., Surzhikov, D.V., Tykezhanova, G.M., Nugumanova, S.M., Kazimov, A.E., Mukasheva, G.Z. (2013b). Assessment of the soil man-made pollution as the example of an industrial city. KarGu Journal, 69, 77-80.

Muzychenko, I., Jamalova, G., Mussina, U., Kazulis, V., Blumberga, D. (2017). Case Study of Lead Pollution in the Roads of Almaty. Energy Procedia, 113, 369-376.

Nezat, C. A., Hatch, S.A,. Uecker, T. (2017). Heavy metal content in urban residential and park soils: A case study in Spokane. Washington, USA. Applied Geochemistry, 78, 186-193.

Nkongolo, K.K., Vaillancourt, A., Dobrzeniecka, S., Mehes, M., Beckett, P. (2008). Metal content in soil and black spruce (Picea mariana) trees in the Sudbury region (Ontario, Canada): low concentration of arsenic, cadmium, and nickel detected near smelter sources. Bulletin of Environmental Contamination and Toxicology, 80, 107-111. 
MEPPRC (Ministry of Environmental Protection of the People's Republic of China) (1995). Environmental Quality Standard for Soils. GB 15618-1995. China Environmental Science Press, Beijing, China.

MEPRK (Ministry of Environmental Protection of the Republic of Kazakhstan) (2004). The norms of maximum permissible concentrations of hazardous substances, organisms and other biological substances polluting the soil. Consignment Order No. 99 of the Ministry of Health of the Republic of Kazakhstan and No. 21 of the MEPRK, Astana, Kazakhstan.

Ramazanova, R. H. (2011). The impact of anthropogenic emissions sources on the heavy metals content in the soil and plants at the south and southeast of Kazakhstan. XI International Scientific and Practical Conference "Problems and Trends of Modern Society" International Academy of Science and Higher Education, London, UK.

RPR (Russian Federation Rospotrebnadzorb) (2006). GN 2.1.7.2041-06: the maximum permissible concentrations (MPC) of chemicals in the soil.

Santos-Frances, F., Martinez-Grana, A., Alonso Rojo, P., Garcia Sanchez, A. (2017). Geochemical Background and Baseline Values Determination and Spatial Distribution of Heavy Metal Pollution in Soils of the Andes Mountain Range (Cajamarca-Huancavelica, Peru). International Journal of Environmental Research and Public Health, 14, 859-881.

Slessarev, E., Lin, Y., Bingham, N., Johnson, J., Dai, Y., Schimel, J. et al. (2016). Water balance creates a threshold in soil $\mathrm{pH}$ at the global scale. Nature, 540, 567-569.

Tepanosyan, G., Sahakyan, L., Belyaeva, O., Maghakyan, N., Saghatelyan, A. (2017). Human health risk assessment and riskiest heavy metal origin identification in urban soils of Yerevan, Armenia. Chemosphere, 184, 1230 - 1240. 
Toth, G., Hermann, T., Szatmari, G., Pasztor, I. (2016). Maps of heavy metals in the soils of the European Union and proposed priority areas for detailed assessment. Science of the Total Environment, 565, 1054-1062.

Turner, A., Lewis, M. (2018). Lead and other heavy metals in soils impacted by exterior legacy paint in residential areas of south west England. Science of the Total Environment, 619620, 1206-1213.

Ungureanu, T., Iancu, G. O., Pintilei, M., Chicos, M. M. (2017). Spatial distribution and geochemistry of heavy metals in soils: A case study from the NE area of Vaslui county, Romania. Journal of Geochemical Exploration, 176, 20-32.

USEPA (United States Environmental Protection Agency) 1992. Behavior of Metals in Soils. USEPA Office of Solid Waste and Emergency Response, EPA/540/S-92/018, Washington, DC, USA.

Wei, B., Yang, L. (2010). A review of heavy metal contaminations in urban soils, urban road dusts and agricultural soils from China. Microchemical Journal, 94, 99-107.

Yan, X., Gao, D., Zhang, F., Zeng, C., Xiang, W., Zhang, M. (2013). Relationships between Heavy Metal Concentrations in Roadside Topsoil and Distance to Road Edge Based on Field Observations in the Qinghai-Tibet Plateau, China. International Journal of Environmental Research and Public Health, 10, 762-775.

Yapiyev, V., Gilman, C.P. Kabdullayeva, T., Suleimanova, A., Shagadatova, A. et al. (2018). Top soil physical and chemical properties in Kazakhstan across a north-south gradient. Scientific Data, 5, 180242. 
529 Zhao, Y., Wang, Z., Sun, W., Huang, B., Shi, X. et al. (2010). Spatial interrelations and multi530 scale sources of soil heavy metal variability in a typical urban-rural transition area in 531 Yangtze River Delta region of China. Geoderma, 156, 216-227.

532

533 


\section{$534 \quad$ List of Figures}

535

536 Fig. 1. Study area with locations of sampling sites

537 Fig. 2. Soil $\mathrm{pH}$ and SOC values $(0-15 \mathrm{~cm}$ depth) through the north-south transect (based on data 538 from Yapiyev et al. (2018))

539 Fig. 3. Box plot for concentrations of PTEs in soil samples $(0-15 \mathrm{~cm}$ depth) (boxes: first, second, 540 and third quartiles; whiskers: $\pm 1.5 \times$ interquartile range)

\section{$542 \quad$ List of Tables}

544 Table 1. Range of concentrations of potentially toxic elements (PTEs) in the soils of present study 545 (0-15 cm depth), background levels of PTEs in Canadian and Chinese soils, and regulatory 546 standards for PTEs for Kazakhstan, Russia, Canada, and China (mg. $\mathrm{kg}^{-1}$ )

547 Table 2. Selected descriptive statistics for PTE concentrations

548 Table 3. Pearson correlation matrix between individual PTEs

549 Table 4. Pearson correlations between PTEs and soil physiochemical characteristics

550 Table 5. Results for two sample $t$-test between two sets of points with distance $<10 \mathrm{~km}$ and $>10$ $551 \mathrm{~km}$ to the nearest settlement

552 Table 6. Pearson correlations between PTEs and distance of sampling sites to nearest settlement

553 Table 7. Results for Shapiro-Wilk test and outlier points with PTE concentrations

554 Supplementary Table 1. Sampling points with data for nearby settlements, concentrations of 555 selected PTEs (0-15 cm depth), and soil properties (from Yapiyev et al. (2018)) 


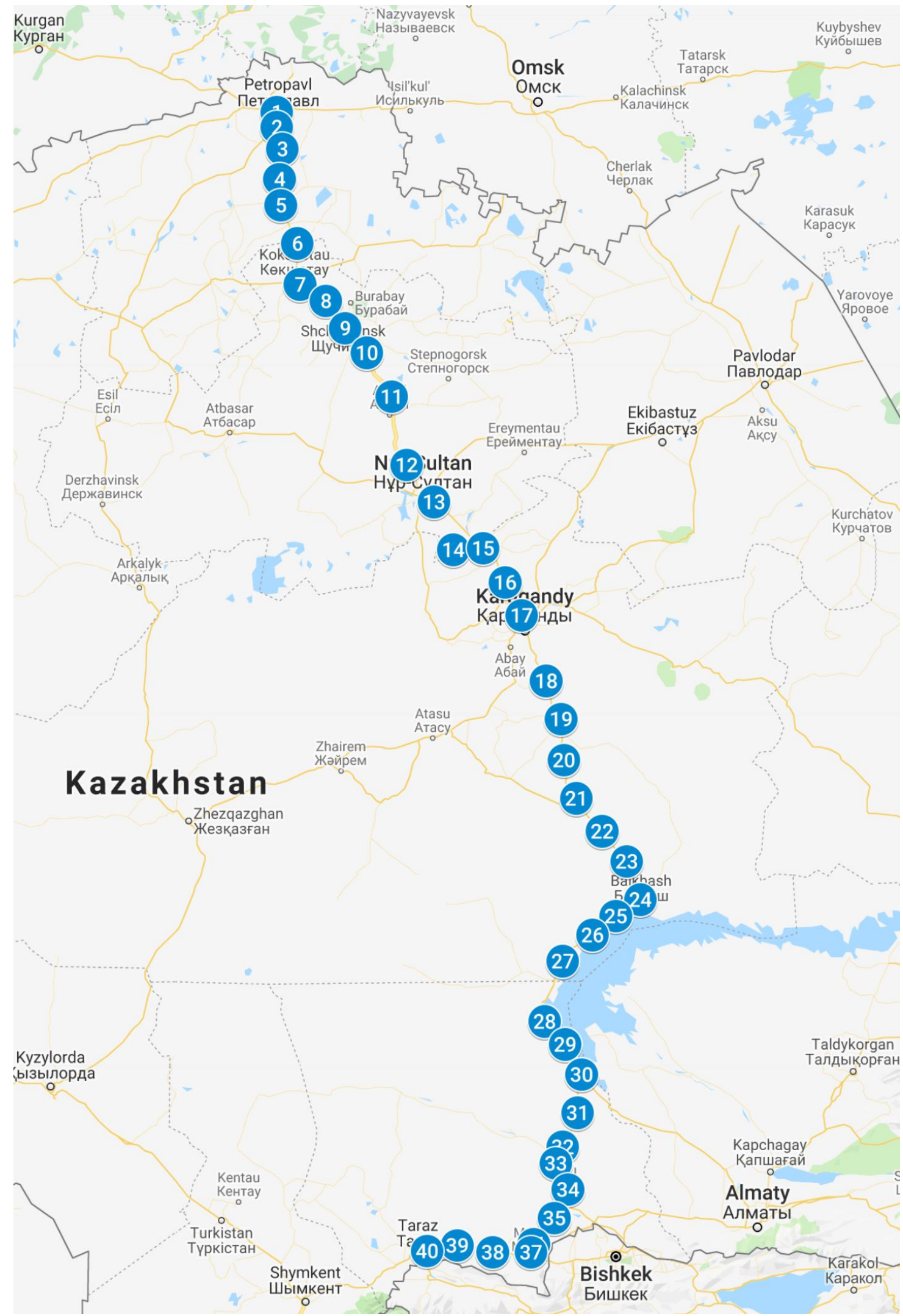

Fig. 1. Study area with locations of sampling sites 


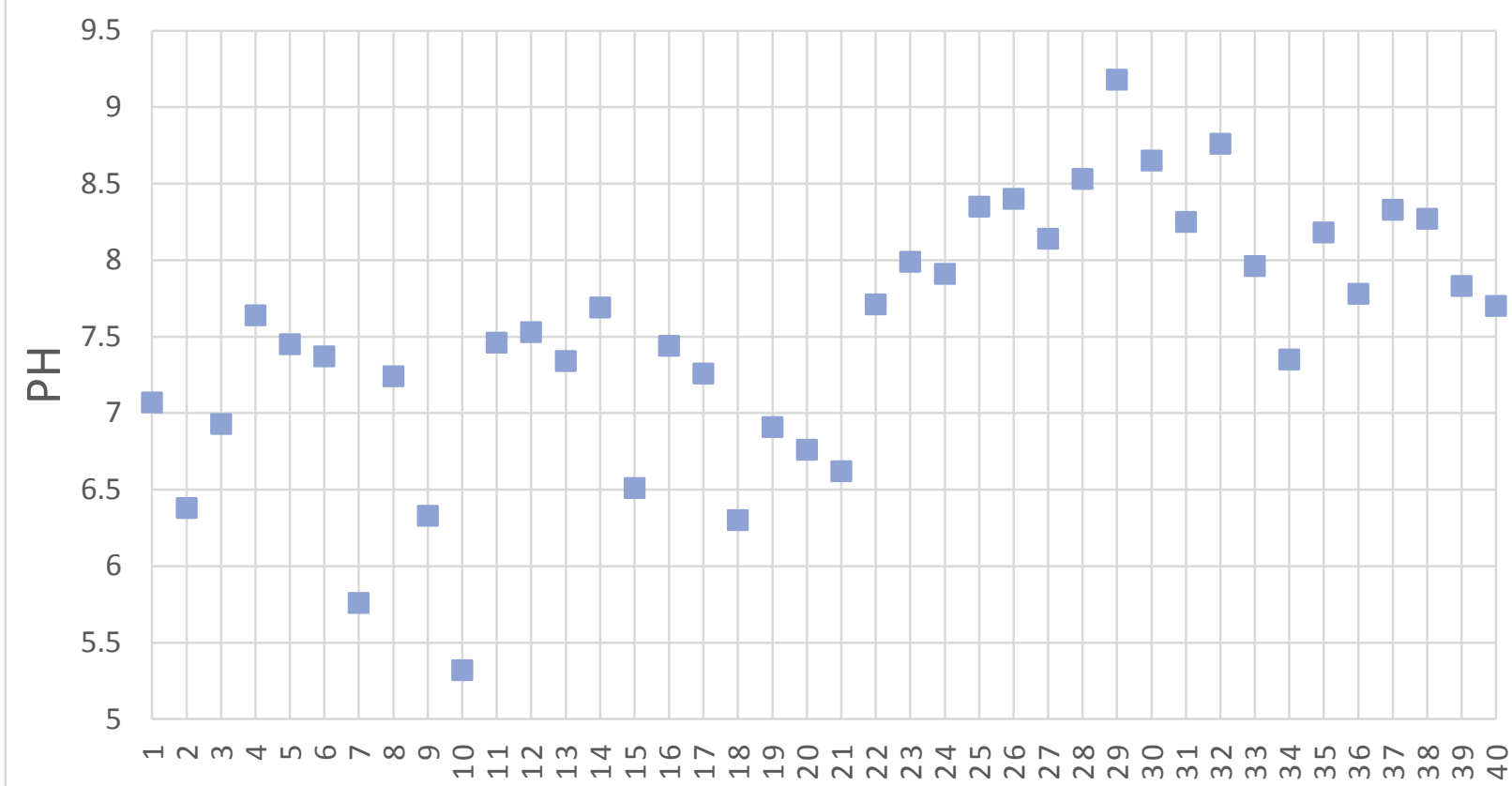
LOCATION

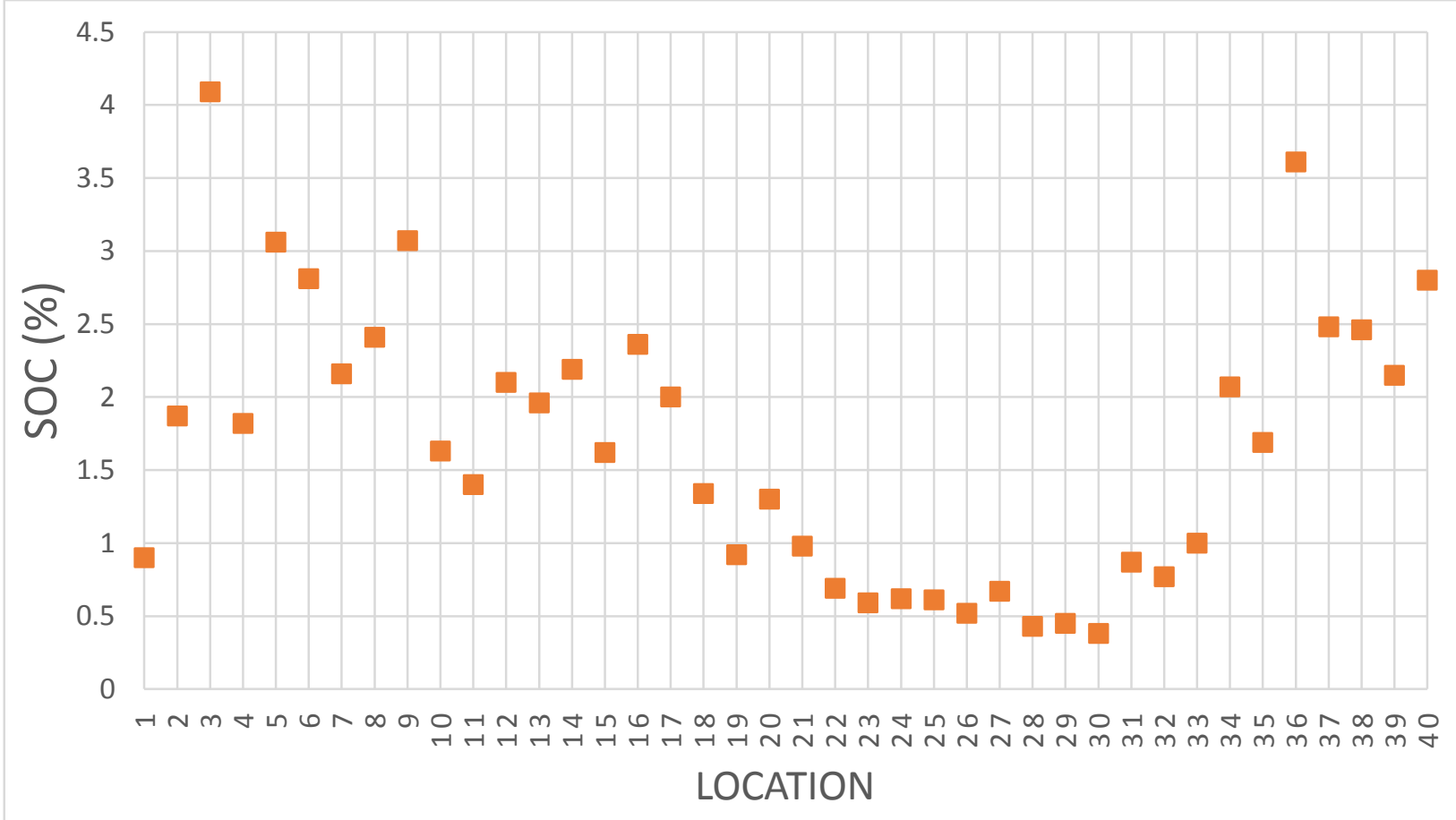

561 Fig. 2. Soil $\mathrm{pH}$ and $\mathrm{SOC}$ values $(0-15 \mathrm{~cm}$ depth) through the north-south transect (based on data 562 from Yapiyev et al. (2018)) 


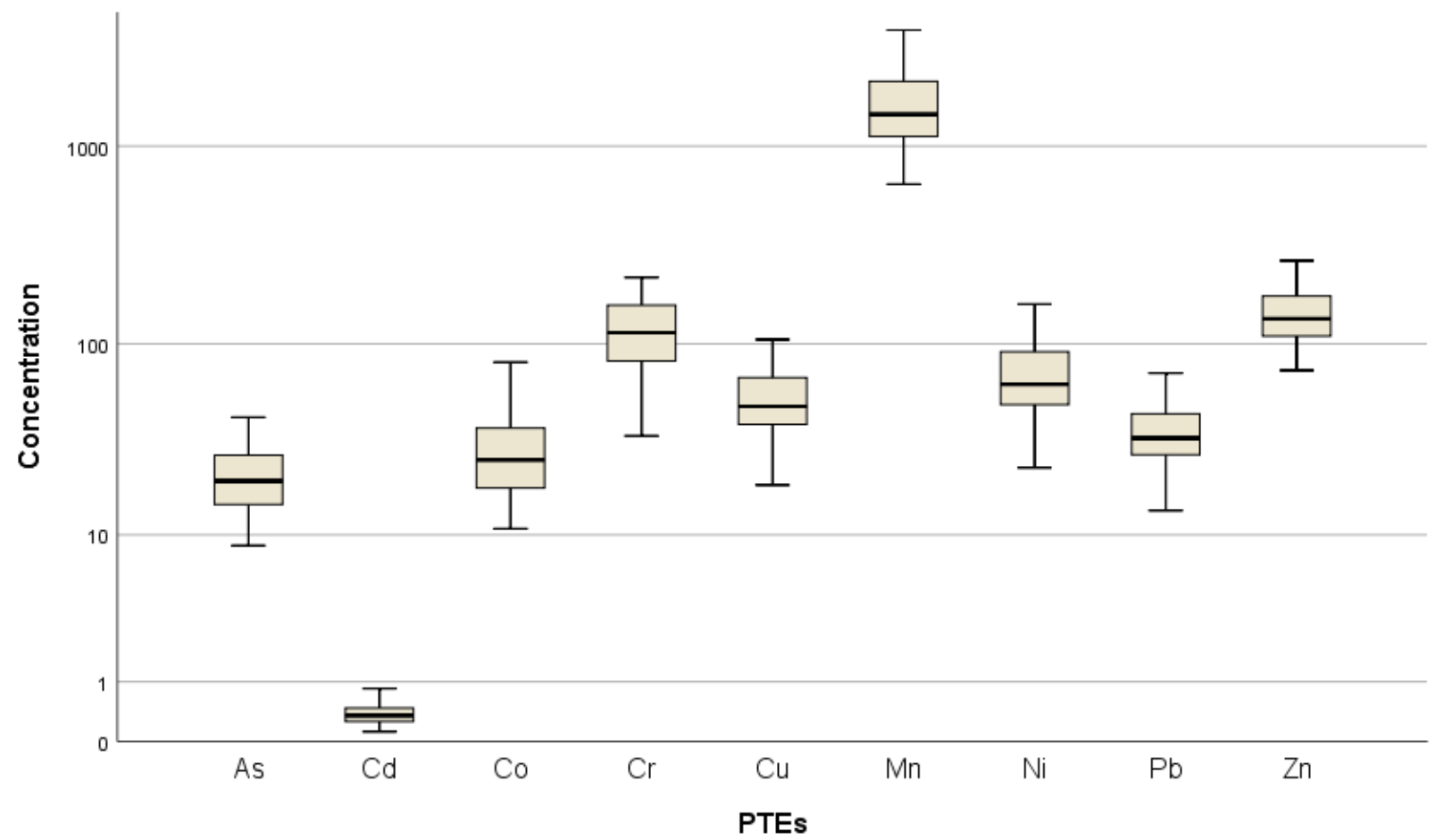

564

565 Fig. 3. Box plot for concentrations of PTEs in soil samples $(0-15 \mathrm{~cm}$ depth) (boxes: first, second,

566 and third quartiles; whiskers: $\pm 1.5 \times$ interquartile range)

567 
568 Table 1. Range of concentrations of potentially toxic elements (PTEs) in the soils of present study 569 (0-15 cm depth), background levels of PTEs in Canadian and Chinese soils, and regulatory standards for PTEs for Kazakhstan, Russia, Canada, and China (mg.kg-1)

571

\begin{tabular}{|l|l|l|l|l|l|l|}
\hline & & $\begin{array}{l}\text { Natural } \\
\text { background } \\
\text { values } \\
\text { PTE } \\
\text { (Quebec, } \\
\text { Canada) } \\
\text { (MDDELCC } \\
\text { 2019) }\end{array}$ & $\begin{array}{l}\text { Natural } \\
\text { background } \\
\text { values } \\
\text { present studina) } \\
\text { (Huamain } \\
\text { et al. 1999) }\end{array}$ & $\begin{array}{l}\text { National } \\
\text { standards } \\
\text { for } \\
\text { Kazakhstan } \\
\text { (MEPRK } \\
\text { 2004) and } \\
\text { Russia } \\
\text { (RPR 2006) }\end{array}$ & $\begin{array}{l}\text { Residential } \\
\text { limits } \\
\text { (Quebec, } \\
\text { Canada) } \\
\text { (MDDELCC } \\
\text { 2019) }\end{array}$ & $\begin{array}{l}\text { Chinese } \\
\text { Environmental } \\
\text { Quality } \\
\text { Standards } \\
\text { (MEPPRC } \\
\text { 1995) }\end{array}$ \\
\hline $\mathrm{As}$ & $8.70-42.0$ & 6 & $\leq 15$ & 2 & 30 & 30 \\
\hline $\mathrm{Cd}$ & $0.12-0.85$ & 1.5 & $\leq 0.20$ & 0.5 & 5 & 0.3 \\
\hline $\mathrm{Co}$ & $10.8-80.6$ & 25 & N/A & 5 & 50 & N/A \\
\hline $\mathrm{Cr}$ & $33.7-217$ & 100 & $\leq 90$ & 6 & 250 & 200 \\
\hline $\mathrm{Cu}$ & $18.6-105$ & 50 & $\leq 35$ & 33 & 100 & 100 \\
\hline $\mathrm{Mn}$ & $353-3.84 \mathrm{E} 3$ & 1,000 & $\mathrm{~N} / \mathrm{A}$ & 1,500 & 1,000 & N/A \\
\hline $\mathrm{Ni}$ & $23.0-159$ & 50 & $\leq 40$ & 4 & 100 & 50 \\
\hline $\mathrm{Pb}$ & $8.60-161$ & 50 & $\leq 35$ & 32 & 500 & 300 \\
\hline $\mathrm{Zn}$ & $23.6-264$ & 140 & $\leq 100$ & 23 & 500 & 250 \\
\hline
\end{tabular}


574 Table 2. Selected descriptive statistics for PTE concentrations

575

\begin{tabular}{|l|l|l|l|l|l|l|l|}
\hline PTE & Average & Min & Max & $\begin{array}{l}\text { Standard } \\
\text { deviation }\end{array}$ & $\begin{array}{l}\text { Coefficient } \\
\text { of variation }\end{array}$ & Skewness & Kurtosis \\
\hline $\mathrm{As}$ & 20.8 & 8.70 & 42.0 & 7.67 & $36.9 \%$ & 0.59 & 0.007 \\
\hline $\mathrm{Cd}$ & 0.38 & 0.12 & 0.85 & 0.18 & $47.9 \%$ & 0.88 & 0.529 \\
\hline $\mathrm{Co}$ & 29.8 & 10.8 & 80.6 & 15.8 & $53.1 \%$ & 1.58 & 2.753 \\
\hline $\mathrm{Cr}$ & 120 & 33.7 & 217 & 46.9 & $39.1 \%$ & 0.28 & -0.762 \\
\hline $\mathrm{Cu}$ & 53.6 & 18.6 & 105 & 20.8 & $38.7 \%$ & 0.65 & -0.291 \\
\hline $\mathrm{Mn}$ & $1.68 \mathrm{E} 3$ & 353 & $3.84 \mathrm{E} 3$ & 762 & $45.4 \%$ & 0.83 & 0.543 \\
\hline $\mathrm{Ni}$ & 69.6 & 23.0 & 159 & 28.7 & $41.2 \%$ & 0.87 & 0.875 \\
\hline $\mathrm{Pb}$ & 38.7 & 8.60 & 161 & 23.8 & $61.6 \%$ & 3.62 & 17.883 \\
\hline $\mathrm{Zn}$ & 140 & 23.6 & 264 & 46.4 & $33.1 \%$ & 0.37 & 0.910 \\
\hline
\end{tabular}

576

577 
578 Table 3. Pearson correlation matrix between individual PTEs

579

\begin{tabular}{|l|l|l|l|l|l|l|l|l|l|}
\hline & As & Cd & Co & Cr & Cu & Mn & Ni & Pb & Zn \\
\hline As & 1 & $0.481^{* *}$ & $0.580^{* *}$ & $0.809^{* *}$ & $0.699^{* *}$ & $0.602^{* *}$ & $0.763^{* *}$ & 0.307 & $0.642^{* *}$ \\
\hline Cd & & 1 & $0.449^{* *}$ & $0.622^{* *}$ & $0.610^{* *}$ & $0.623^{* *}$ & $0.482^{* *}$ & 0.295 & $0.583^{* *}$ \\
\hline Co & & & 1 & $0.699^{* *}$ & $0.577^{* *}$ & $0.767^{* *}$ & $0.859^{* *}$ & $0.501^{* *}$ & $0.513^{* *}$ \\
\hline $\mathbf{C r}$ & & & & 1 & $0.594^{* *}$ & $0.713^{* *}$ & $0.873^{* *}$ & $0.321^{*}$ & $0.671^{* *}$ \\
\hline $\mathbf{C u}$ & & & & & 1 & $0.628^{* *}$ & $0.623^{* *}$ & $0.417^{* *}$ & $0.763^{* *}$ \\
\hline $\mathbf{M n}$ & & & & & & 1 & $0.745^{* *}$ & $0.670^{* *}$ & $0.725^{* *}$ \\
\hline $\mathbf{N i}$ & & & & & & & 1 & 0.293 & $0.658^{* *}$ \\
\hline $\mathbf{P b}$ & & & & & & & & 1 & $0.424^{* *}$ \\
\hline $\mathbf{Z n}$ & & & & & & & & & 1 \\
\hline
\end{tabular}

$581 \quad * *$ Significant at the 0.01 level 
583 Table 4. Pearson correlations between PTEs and soil physiochemical characteristics

584

\begin{tabular}{|c|c|c|c|c|c|c|c|c|c|c|c|}
\hline & As & Cd & Co & $\mathrm{Cr}$ & $\mathbf{C u}$ & Mn & $\mathbf{N i}$ & $\mathbf{P b}$ & $\mathbf{Z n}$ & pH & SOC \\
\hline pH & -0.213 & 0.012 & -0.070 & -0.302 & 0.086 & -0.139 & -0.127 & -0.046 & -0.107 & 1 & $-\overline{-} 350^{\prime \prime}$ \\
\hline OC & $0.516^{* *}$ & 0.170 & $0.549^{* *}$ & $0.564^{* *}$ & 0.273 & $0.510^{* *}$ & $0.669^{* * *}$ & 0.128 & $0.394^{*}$ & $0.350^{*}$ & 1 \\
\hline
\end{tabular}

* Significant at the 0.05 level

$586 \quad * *$ Significant at the 0.01 level

587 
588 Table 5. Results for two sample $t$-test between two sets of points with distance $<10 \mathrm{~km}$ and $>10$ $589 \mathrm{~km}$ to the nearest settlement

590

\begin{tabular}{|c|c|c|c|c|c|}
\hline Element & $\begin{array}{l}\text { Average } \\
\text { concentration } \\
\text { for } \mathbf{d}<\mathbf{1 0} \mathbf{~ k m} \\
\left(\mathrm{mg} \times \mathrm{kg}^{-1}\right)\end{array}$ & $\begin{array}{l}\text { Average } \\
\text { concentration } \\
\text { for } \mathbf{d}>\mathbf{1 0} \mathbf{~ k m} \\
\left(\mathrm{mg} \times \mathrm{kg}^{-1}\right)\end{array}$ & $p$-value & $\begin{array}{l}t- \\
\text { statistic }\end{array}$ & $\begin{array}{l}\text { Null } \\
\text { hypothesis }\end{array}$ \\
\hline As & 22.5 & 19.1 & 0.161 & 1.432 & Accepted \\
\hline $\mathrm{Cd}$ & 0.41 & 0.35 & 0.314 & 1.021 & Accepted \\
\hline Co & 33.3 & 26.2 & 0.158 & 1.439 & Accepted \\
\hline $\mathrm{Cr}$ & 135 & 105 & 0.044 & 2.087 & Rejected \\
\hline $\mathrm{Cu}$ & 53.2 & 54.1 & 0.893 & -0.134 & Accepted \\
\hline $\mathrm{Mn}$ & $1.80 \mathrm{E}+03$ & $1.56 \mathrm{E}+03$ & 0.334 & 0.978 & Accepted \\
\hline $\mathrm{Ni}$ & 76.7 & 62.5 & 0.118 & 1.601 & Accepted \\
\hline $\mathrm{Pb}$ & 36.6 & 40.8 & 0.583 & -0.554 & Accepted \\
\hline $\mathrm{Zn}$ & 141 & 139 & 0.889 & 0.14 & Accepted \\
\hline
\end{tabular}

591

592

593 
594 Table 6. Pearson correlations between PTEs and distance of sampling sites to nearest settlement 595

\begin{tabular}{|l|l|l|l|l|l|l|l|l|l|}
\hline & As & Cd & Co & Cr & Cu & Mn & Ni & Pb & Zn \\
\hline Distance & -0.228 & -0.257 & -0.327 & -0.415 & 0.060 & -0.267 & -0.364 & -0.051 & -0.196 \\
\hline $\mathbf{r}$ & 0.052 & 0.066 & 0.107 & 0.172 & $0.004^{* *}$ & 0.071 & 0.133 & $0.003^{* *}$ & $0.038^{*}$ \\
\hline
\end{tabular}

** Significant at the 0.01 level 
Table 7. Results for Shapiro-Wilk test and outlier points with PTE concentrations

600

\begin{tabular}{|l|l|l|l|l|}
\hline PTE & $\boldsymbol{p}$-value & $\mathbf{W}$ & Distribution a & $\begin{array}{l}\text { Outlier points } \\
\text { (concentration inmg } \times \mathrm{kg}^{-1} \text { ) }\end{array}$ \\
\hline $\mathrm{As}$ & 0.150 & 0.9585 & Normal & S9 $(42.0)$ \\
\hline $\mathrm{Cd}$ & 0.011 & 0.9251 & Non-normal & S32 (0.85), S10 (0.78), S36 (0.76) \\
\hline $\mathrm{Co}$ & 0.000 & 0.8527 & Non-normal & S36 (80.6), S35 (75.5) \\
\hline $\mathrm{Cr}$ & 0.246 & 0.9649 & Normal & S7 (217) \\
\hline $\mathrm{Cu}$ & 0.050 & 0.9447 & Non-normal & S28 (105) \\
\hline $\mathrm{Mn}$ & 0.070 & 0.9490 & Normal & S36 (3.84E+03), S10 (3.30E+03) \\
\hline $\mathrm{Ni}$ & 0.046 & 0.9437 & Non-normal & S36 (159) \\
\hline $\mathrm{Pb}$ & 0.000 & 0.6824 & Non-normal & S11 (161) \\
\hline $\mathrm{Zn}$ & 0.431 & 0.9725 & Normal & S19 (264), S32 (243) \\
\hline
\end{tabular}

${ }^{\text {a }}$ Normality is rejected if $p<0.050$

${ }^{\mathrm{b}}$ determined via Q-Q plots and histograms

601

602 
603 Supplementary Table 1. Sampling points with data for nearby settlements, concentrations of selected PTEs (0-15 cm depth), and 604 soil properties from Yapiyev et al. (2018

605

\begin{tabular}{|c|c|c|c|c|c|c|c|c|c|c|c|c|c|c|c|c|}
\hline \multirow{2}{*}{$\begin{array}{l}\text { Sample } \\
\text { ID }\end{array}$} & \multirow{2}{*}{ Soil type } & \multirow{2}{*}{ Location } & \multirow{2}{*}{ Nearest settlement } & \multirow{2}{*}{$\begin{array}{l}\text { Distance } \\
(\mathbf{k m})\end{array}$} & \multirow{2}{*}{ Population } & \multicolumn{9}{|c|}{ Elemental concentration $\left(\mathrm{mg} \times \mathrm{kg}^{-1 \cdot}\right)$} & \multirow[t]{2}{*}{$\begin{array}{l}\text { pH } \\
(-)\end{array}$} & \multirow[t]{2}{*}{$\begin{array}{l}\text { SOC } \\
(\%)\end{array}$} \\
\hline & & & & & & As & Cd & Co & $\mathbf{C r}$ & $\mathbf{C u}$ & Mn & $\mathbf{N i}$ & $\mathbf{P b}$ & $\mathbf{Z n}$ & & \\
\hline $\mathrm{S} 1$ & Chernozem & $\begin{array}{ll}\text { Road } & \text { street } \\
\text { Potanina } & \\
\end{array}$ & Petropavlovsk city & 0 & 201,446 & 9.66 & 0.14 & 23.3 & 54.7 & 18.6 & 642 & 30.9 & 14.0 & 73.2 & 7.07 & 0.90 \\
\hline S2 & Chernozem & Highway A 1 & Beiterek village & 2.7 & 9,679 & 13.1 & 0.14 & 22.7 & 67.3 & 28.8 & $1.38 \mathrm{E} 3$ & 46.4 & 26.7 & 87.9 & 6.38 & 1.87 \\
\hline S3 & Chernozem & Highway A 1 & Astrakhanka village & 3.2 & 6,313 & 21.2 & 0.41 & 37.6 & 157 & 64.5 & $2.32 \mathrm{E} 3$ & 94.4 & 38.2 & 186 & 6.93 & 4.09 \\
\hline S4 & Chernozem & Highway A 1 & Amangel'dy village & 20.3 & 7,569 & 17.8 & 0.31 & 26.0 & 128 & 39.9 & $1.21 \mathrm{E} 3$ & 72.0 & 27.7 & 99.5 & 7.64 & 1.82 \\
\hline S5 & Chernozem & Highway A 1 & Rostovka village & 17.6 & 2,290 & 26.8 & 0.36 & 43.1 & 196 & 67.9 & $2.34 \mathrm{E} 3$ & 107 & 41.8 & 189 & 7.45 & 3.06 \\
\hline S6 & Chernozem & Highway A 343 & Kokshetau town & 35.6 & 135,106 & 21.0 & 0.26 & 26.1 & 133 & 44.9 & $1.18 \mathrm{E} 3$ & 74.4 & 26.6 & 130 & 7.37 & 2.81 \\
\hline S7 & Chernozem & Highway A 1 & Kokshetau town & 1.3 & 135,106 & 29.4 & 0.46 & 44.6 & 217 & 83.4 & $2.18 \mathrm{E} 3$ & 112 & 40.0 & 169 & 5.76 & 2.16 \\
\hline S8 & Chernozem & Highway A 1 & Kenesary village & 1.4 & 1,598 & 32.7 & 0.42 & 55.4 & 185 & 86.9 & $2.11 \mathrm{E} 3$ & 119 & 40.0 & 181 & 7.24 & 2.41 \\
\hline S9 & Chernozem & Highway A 1 & Shchuchinsk town & 6.3 & 44,106 & 42.0 & 0.51 & 44.9 & 192 & 80.1 & $2.42 \mathrm{E} 3$ & 96.3 & 39.6 & 182 & 6.33 & 3.07 \\
\hline S10 & Chernozem & $\begin{array}{l}\text { Highway A 1, } \\
\text { Gas station } \\
\text { "Sinooil" }\end{array}$ & Makinka village & 2.3 & 2,013 & 23.5 & 0.78 & 31.8 & 200 & 51.1 & $3.30 \mathrm{E} 3$ & 73.1 & 70.9 & 210 & 5.32 & 1.63 \\
\hline S11 & Chernozem & Highway A 1 & Akkol village & 17.5 & 14,217 & 17.4 & 0.31 & 54.1 & 109 & 55.1 & $3.00 \mathrm{E} 3$ & 58.8 & 161 & 128 & 7.46 & 1.40 \\
\hline $\mathrm{S} 12$ & Kastanozem & Highway A 1 & Bazoygir village & 3.3 & 2,526 & 26.6 & 0.29 & 34.6 & 131 & 53.4 & $2.07 \mathrm{E} 3$ & 87.5 & 42.9 & 140 & 7.53 & 2.10 \\
\hline S13 & Kastanozem & Highway M 36 & Astana city & 0 & 613,006 & 16.5 & 0.25 & 18.4 & 79.5 & 38.5 & $1.09 \mathrm{E} 3$ & 53.4 & 23.8 & 109 & 7.34 & 1.96 \\
\hline S14 & Kastanozem & Highway M 36 & Anar village & 29.4 & 1,117 & 27.7 & 0.34 & 26.5 & 128 & 54.2 & $1.43 \mathrm{E} 3$ & 69.1 & 30.3 & 135 & 7.69 & 2.19 \\
\hline S15 & Kastanozem & Highway M 36 & Anar village & 1.4 & 1,117 & 24.1 & 0.40 & 22.0 & 112 & 43.4 & $1.31 \mathrm{E} 3$ & 60.7 & 31.8 & 115 & 6.51 & 1.62 \\
\hline S16 & Kastanozem & Highway M 36 & Temirtau town & 22 & 169,590 & 8.9 & 0.21 & 15.3 & 72.6 & 38.8 & 982 & 45.5 & 31.5 & 134 & 7.44 & 2.36 \\
\hline S17 & Kastanozem & Highway M 36 & Karaganda town & 3.5 & 459,778 & 13.5 & 0.31 & 16.4 & 87.6 & 37.4 & $1.15 \mathrm{E} 3$ & 49.2 & 27.0 & 132 & 7.26 & 2.00 \\
\hline S18 & $\begin{array}{c}\text { Calcisol + } \\
\text { Solonetz } \\
\end{array}$ & Highway M 36 & Akbastau village & 17.6 & 3,300 & 18.8 & 0.29 & 19.2 & 92.6 & 40.6 & $1.38 \mathrm{E} 3$ & 52.8 & 30.4 & 130 & 6.30 & 1.34 \\
\hline S19 & $\begin{array}{c}\text { Calcisol + } \\
\text { Solonetz }\end{array}$ & Highway M 36 & Aksu-Ayuly village & 10.9 & 4,586 & 32.5 & 0.49 & 32.6 & 157 & 90.1 & $1.44 \mathrm{E} 3$ & 86.0 & 61.8 & 264 & 6.91 & 0.92 \\
\hline S20 & $\begin{array}{c}\text { Calcisol + } \\
\text { Solonetz }\end{array}$ & Highway M 36 & Aksu-Ayuly village & 35.1 & 4,586 & 14.0 & 0.17 & 14.9 & 71.5 & 33.2 & 966 & 38.4 & 25.6 & 98.7 & 6.76 & 1.30 \\
\hline $\mathrm{S} 21$ & Arenosol & Highway M 36 & Akshatau village & 10.4 & 1,149 & 13.8 & 0.26 & 16.7 & 80.4 & 40.4 & $1.02 \mathrm{E} 3$ & 47.6 & 20.3 & 109 & 6.62 & 0.98 \\
\hline
\end{tabular}




\begin{tabular}{|c|c|c|c|c|c|c|c|c|c|c|c|c|c|c|c|c|}
\hline S22 & Arenosol & Highway M 36 & Akzhal village & 22.8 & 3,397 & 24.5 & 0.24 & 16.5 & 129 & 32.7 & $1.16 \mathrm{E} 3$ & 57.2 & 26.4 & 110 & 7.71 & 0.69 \\
\hline S23 & $\begin{array}{c}\text { Arenosol + } \\
\text { Solonetz }\end{array}$ & Highway M 36 & Balkhash town & 55.6 & 68,883 & 14.9 & 0.12 & 16.3 & 68.6 & 36.1 & $1.07 \mathrm{E} 3$ & 48.4 & 23.6 & 92.3 & 7.99 & 0.59 \\
\hline S24 & $\begin{array}{c}\text { Arenosol + } \\
\text { Solonetz }\end{array}$ & Highway M 36 & Konirat village & 3.1 & 3,103 & 13.1 & 0.73 & 14.4 & 116 & 25.6 & 353 & 33.3 & 8.6 & 23.6 & 7.91 & 0.62 \\
\hline S25 & $\begin{array}{c}\text { Arenosol + } \\
\text { Solonetz }\end{array}$ & Highway M 36 & $\begin{array}{l}\text { Balkhash } \quad \text { lake, } \\
\text { recreation area Gulf } \\
\begin{array}{l}\text { Stream, } \\
\text { town }\end{array}\end{array}$ & 28.9 & 68,883 & 8.70 & 0.14 & 10.8 & 44.8 & 26.4 & 854 & 35.0 & 13.6 & 80.9 & 8.35 & 0.61 \\
\hline S26 & Arenosol & Highway M 36 & $\begin{array}{l}\text { Balkhash lake, } \\
\text { Balkhash town }\end{array}$ & 64.4 & 68,883 & 14.4 & 0.15 & 17.6 & 69.4 & 37.3 & $1.09 \mathrm{E} 3$ & 44.7 & 32.1 & 107 & 8.40 & 0.52 \\
\hline S27 & $\begin{array}{c}\text { Solonchak + } \\
\text { Solonetz }\end{array}$ & Highway M 36 & Saryshagan village & 15.7 & 4,429 & 17.8 & 0.45 & 23.4 & 100 & 52.6 & $1.71 \mathrm{E} 3$ & 59.7 & 39.3 & 135 & 8.14 & 0.67 \\
\hline S28 & Arenosol & Highway M 36 & Akbakay village & 72.7 & 1,473 & 24.0 & 0.52 & 22.0 & 90.0 & 105 & $1.76 \mathrm{E} 3$ & 51.8 & 48.9 & 144 & 8.53 & 0.43 \\
\hline S29 & Arenosol & Highway M 36 & $\begin{array}{l}\text { Balkhash lake } \\
\text { chemical plant } \\
\text { "Jambul Cement" }\end{array}$ & 9.2 & 721 & 20.6 & 0.32 & 22.8 & 110 & 68.6 & $1.45 \mathrm{E} 3$ & 50.7 & 48.1 & 124 & 9.18 & 0.45 \\
\hline S30 & Arenosol & Highway M 36 & Shyganak village & 13.9 & 2,402 & 16.8 & 0.40 & 18.3 & 83.3 & 42.7 & $1.18 \mathrm{E} 3$ & 53.3 & 36.7 & 136 & 8.65 & 0.38 \\
\hline S31 & Arenosol & Highway M 36 & Aksuek village & 42.1 & 1,231 & 11.7 & 0.36 & 13.8 & 33.7 & 66.3 & 726 & 23.0 & 27.9 & 127 & 8.25 & 0.87 \\
\hline S32 & Arenosol & Highway A 358 & $\begin{array}{l}\text { Birlik } \\
\text { village }\end{array}$ & 16.7 & 3,157 & 16.8 & 0.85 & 30.6 & 127 & 85.6 & $2.88 \mathrm{E} 3$ & 65.7 & 44.7 & 243 & 8.76 & 0.77 \\
\hline S33 & $\begin{array}{c}\text { Chemozem + } \\
\text { Solonetz }\end{array}$ & Highway A 358 & Kenes village & 0.5 & 2,332 & 16.2 & 0.36 & 33.9 & 157 & 44.2 & $1.91 \mathrm{E} 3$ & 99.1 & 31.4 & 161 & 7.96 & 1.00 \\
\hline S34 & Regosol & Highway A 358 & $\begin{array}{l}\text { Chu river } 200 \mathrm{~m} \text {, Tole } \\
\text { Bi village }\end{array}$ & 1.3 & 19,000 & 20.4 & 0.29 & 24.5 & 97.7 & 43.7 & $1.69 \mathrm{E} 3$ & 63.4 & 32.9 & 117 & 7.35 & 2.07 \\
\hline S35 & Regosol & Highway P 29 & Aspara village & 5.1 & 1,086 & 17.5 & 0.43 & 75.5 & 143 & 58.2 & $1.90 \mathrm{E} 3$ & 104 & 32.7 & 134 & 8.18 & 1.69 \\
\hline S36 & Regosol & Highway P 29 & Oytal village & 13.4 & 4,181 & 33.0 & 0.76 & 80.6 & 190 & 91.4 & $3.84 \mathrm{E} 3$ & 159 & 65.3 & 195 & 7.78 & 3.61 \\
\hline S37 & Umbrisol & Highway A 2 & Zhambul village & 4.8 & 6,633 & 29.0 & 0.53 & 36.4 & 163 & 63.5 & $2.13 \mathrm{E} 3$ & 97.7 & 46.9 & 191 & 8.33 & 2.48 \\
\hline S38 & Umbrisol & Highway A 2 & Kokdonen village & 0.5 & 2,063 & 21.4 & 0.29 & 29.6 & 104 & 44.9 & $1.76 \mathrm{E} 3$ & 72.5 & 36.3 & 146 & 8.27 & 2.46 \\
\hline S39 & Umbrisol & Highway A 2 & Terenozek village & 4.7 & 2,060 & 31.4 & 0.59 & 37.8 & 180 & 68.3 & $2.06 \mathrm{E} 3$ & 103 & 48.5 & 166 & 7.83 & 2.15 \\
\hline S40 & Arenosol & $\begin{array}{l}\text { Highway A 2, } \\
\text { Gas station } \\
\text { "Sinooil" }\end{array}$ & Talas village & 2.3 & 2,921 & 28.0 & 0.51 & 39.8 & 144 & 60.2 & $2.71 \mathrm{E} 3$ & 87.8 & 51.0 & 181.3 & 7.70 & 2.80 \\
\hline
\end{tabular}

